\title{
ANALISIS PENGGUNAAN SISTEM PENDAFTARAN ONLINE (E-HEALTH) BERDASARKAN UNIFIED THEORY OF ACCEPPTANCE AND USE OF TECHNOLOGY (UTAUT)
}

\author{
ANALYSIS THE USE OF E-HEALTH BASED ON UNIFIED THEORY OF ACCEPPTANCE AND USE OF \\ TECHNOLOGY (UTAUT)
}

\author{
Nurus Sa'idah \\ Perhimpunan Sarjana Kesehatan Masyarakat Indonesia (Persakmi) Kota Surabaya \\ E-mail: nurus.saidah-12@fkm.unair.ac.id
}

\begin{abstract}
Surabaya is a pioneer of E-Health innovation in Indonesia by providing online registration system to facilitate to take a quenue number anytime anywhere. The users online registration at RSUD dr.M. Soewandhie Surabaya is the largest, but dissatisfaction figure of online registration services reached $31,4 \%$. Therefore, the purpose of this research is to analyze use behavior online registration at RSUD dr.M. Soewandhie based on Unified Theory of Acceptance and Use of Technology (UTAUT). This research was an analytic observational with quantitative approach and cross sectional design. Sample were collected by systematic random sampling and consist of 50 users and 50 nonusers. The result showed that individual characteristic which has $p$ value below 0,05 was experience, knowledge and IT skills. Performance expectancy $(p=0,044)$ significantly influence behavioral intention, whereas effort expectancy $(p=0,982)$ and social influence $(p=0,124)$ do not. Facilitating condition $(p=0,812)$ and behavioral intention $(p=0,189)$ had no influence with use behavior because $p$ value was above 0,05 . In conclusion, performance expectancy has a significant influence with behavioral intention, therefore experience, knowledge and IT skills had influence with use behavior online registration in RSUD dr.M. Soewandhie Surabaya.
\end{abstract}

Keyword: e-Health, online registration, Unified Theory of Acceptance and Use of Technology (UTAUT), use behavior

\section{PENDAHULUAN}

Pelayanan kesehatan secara global
dianggap industri jasa terbesar yang menjadi
prioritas utama serta merupakan investasi yang sangat besar yang tumbuh dengan pesat di sebagian besar negara. E-health merupakan salah satu inovasi yang dilakukan untuk mengatasi hambatan tersebut. E-Health atau elektronik kesehatan, yang pada dasarnya didorong oleh penggunaan teknologi informasi dan komunikasi dalam kesehatan memiliki potensi untuk mengubah industri kesehatan seluruh dunia dalam hal infra struktur, biaya dan kualitas layanan (Wickramasinghe dan Goldberg, 2004).

$$
\text { WHO (2008), mendefisikan E-Health }
$$

sebagai "the use of information and communication technologies (ICT) for health". WHO mendorong kepada setiap negara untuk menyusun rencana strategis jangka panjang untuk mengembangkan layanan $E$-Health di berbagai bidang kesehatan baik untuk administrasi kesehatan, kerangka legal dan regulasi, infrastruktur serta mekanisme kemitraan publik dan swasta.

Inovasi E-Health di Indonesia dipelopori oleh pemerintah Kota Surabaya dengan tujuan untuk memudahkan masyarakat yang akan datang ke puskesmas dan rumah sakit untuk mendaftar secara online, baik pasien baru maupun pasien lama. Sehingga, tidak ada lagi antrian panjang yang terjadi dan pasien pun dapat memperkirakan waktu untuk datang ke fasilitas kesehatan yang dituju.

Antusias masyarakat Surabaya dalam memanfaatkan sistem pendaftaran online cukup tinggi berdasarkan data antrian online pada situs www.surabaya-ehealth.com . Berikut ini adalah lima fasilitas kesehatan milik pemerintah dengan 
pengguna antrian online tertinggi pada bulan Maret 2016 disajikan pada tabel 1.

Tabel 1. Lima Fasilitas Kesehatan dengan Pengguna Antrian Online Tertinggi

\begin{tabular}{clc}
\hline No. & \multicolumn{1}{c}{$\begin{array}{c}\text { Nama Fasilitas } \\
\text { Kesehatan }\end{array}$} & $\begin{array}{c}\text { Jumlah Pengguna } \\
\text { Antrian Online }\end{array}$ \\
\hline 1. & $\begin{array}{l}\text { RSUD dr. M. } \\
\text { Soewandhie }\end{array}$ & 3069 \\
\hline 2. & Puskesmas Jagir & 1009 \\
\hline 3. & $\begin{array}{l}\text { Puskesmas } \\
\text { Ketabang }\end{array}$ & 703 \\
\hline 4. & $\begin{array}{l}\text { RSUD Bhakti } \\
\text { Dharma Husada }\end{array}$ & 326 \\
\hline 5. & $\begin{array}{l}\text { Puskesmas } \\
\text { Simomulyo }\end{array}$ \\
\hline
\end{tabular}

(Sumber: website surabaya-ehealth, 2016)

Pada Tabel 1 dapat diketahui bahwa sistem pendaftaran online di RSUD dr. M. Soewandhi berjalan dengan estimasi rata-rata pengguna per hari adalah 154 orang. RSUD dr. M. Soewandhie memiliki fasilitas mesin E-Kios yang terhubung dengan website pendaftaran online E-Health, sehingga pasien yang berkunjung dapat memilih melakukan secara online melalui E-Kios ataupun pendaftaran secara manual dengan mengambil nomor antrian yang telah disediakan petugas.

Peneliti melakukan pengambilan data awal dengan melakukan survey pada 35 pengguna mesin E-Kios diperoleh bahwa sebesar 68,6\% pengguna pendaftaran online dengan mesin E-Kios merasa puas. Sedangkan $31,4 \%$ pengguna merasa tidak puas saat menggunakan mesin E-Kios.

Alasan responden atas rasa ketidakpuasan mereka antara lain karena terkadang mesin E-Kios error serta koneksi yang lambat, selain itu petunjuk pemakaian mesin E-Kios tidak mudah dipahami oleh beberapa orang sehingga memerlukan bantuan petugas ataupun pengguna lainnya. Sehingga perlu dilakukan penelitian untuk mengevaluasi sikap penerimaan masyarakat dalam menggunakan fasilitas sistem pendaftaran online untuk menghindari rendahmya pemanfaatan sistem pendaftaran online.

Venkatesh, et al. (2003) mengemukakan bahwa penerimaan pengguna dari suatu sistem informasi yang baru dipengaruhi oleh berbagai faktor sehingga dikembangkan model yang disebut Unified Theory of Acceptance and Use of Technology (UTAUT). Penelitian ini bertujuan untuk menganalisa use behavior pengguna sistem pendaftaran online (E-Health) di RSUD dr. M. Soewandhi Surabaya yang telah berjalan lebih dari satu tahun. Diharapkan dengan penggunaan model UTAUT, penelitian ini dapat menyajikan pengaruh dari faktor-faktor dalam model tersebut

\section{PUSTAKA}

E-Health didefinisikan sebagai penggunaan teknologi informasi dan komunikasi untuk mendukung bidang kesehatan dan hal-hal yang berkaitan dengan kesehatan, termasuk pelayanan kesehatan, pengawasan kesehatan, literatur kesehatan, pendidikan kesehatan, pengetahuan dan penelitian (Joaquin, et al , 2010).

Salah satu penerapan inovasi E-Health di Kota Surabaya adalah sitem pendaftaran online bertujuan untuk memudahkan masyarakat yang akan datang ke Puskesmas maupun Rumah Sakit Pemerintah untuk mendaftar secara online, baik pasien baru maupun pasien lama.

Aplikasi E-Health tersedia di mesin E-Kios yang sudah tersedia di seluruh kantor kecamatan dan kelurahan, beberapa Puskesmas dan dua Rumah Sakit milik Pemerintah Kota Surabaya. E- 
Health juga dapat diakses melalui website www.ehealth.surabaya.go.id/pendaftaran ,sehingga masyarakat dapat mendaftar secara online kapanpun dimanapun.

Keberhasilan suatu sistem sangat bergantung pada penerimaan dan penggunaan dari individu-individu, dari pengukuran penerimaan dan penggunaan dapat menjelaskan tingkat kepuasan dari penggunaan sistem dan mempunyai dampak langsung terhadap peningkatan produktifitas suatu organisasi (Sari ,2003).

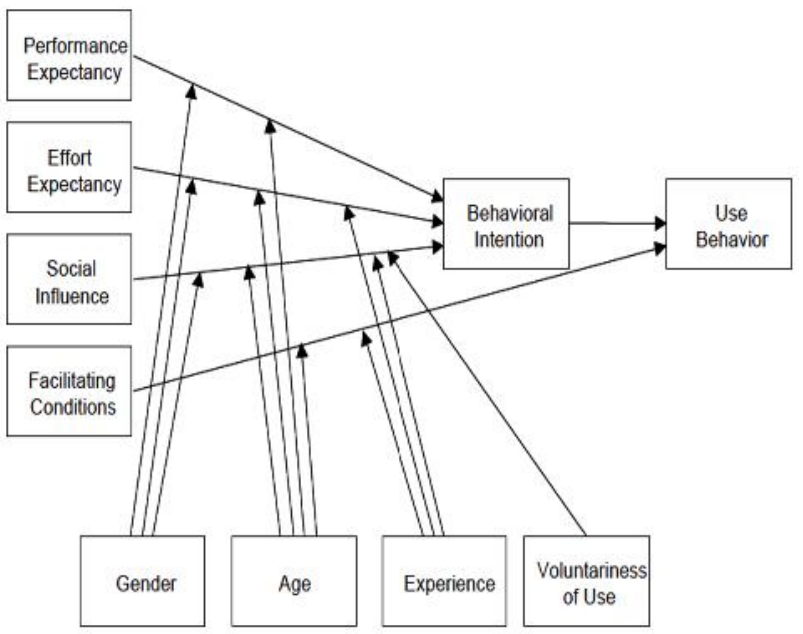

Gambar 1. Model UTAUT oleh Venkatesh et al (2003)

Venkatesh, et al. (2003) mengembangkan

Unified Theory of Acceptance and Use of Technology (UTAUT) yang merupakan integrasi penyempurnaan dari delapan teori perilaku lain dalam menjelaskan penerimaan pengguna sistem informasi. Berikut adalah penjelasan dari variabel pada UTAUT:

Performance Expectancy

Performance Expectancy merupakan tingkat kepercayaan individu bahwa penggunaan sistem yang ada dapat membantu mereka untuk mendapatkan suatu manfaat yang dapat membantu mempermudah pekerjaannya.

\section{Effort Expectancy}

Effort Expectancy didefinisikan sebagai tingkatan kemudahan penggunaan sistem yang dapat membantu mengurangi upaya (tenaga dan waktu) individu tersebut dalam menyelesaikan pekerjaannya. Kemudahan dalam penggunaan dapat menimbulkan perasaan minat dalam diri seseorang bahwa sistem itu mempunyai kegunaan dan menimbulkan rasa nyaman saat penggunaannya ( Venkatesh dan Davis, 2000).

\section{Social Influence}

Jati dan Laksito (2012) menyimpulkan bahwa semakin banyak pengaruh yang diberikan sebuah lingkungan terhadap calon pengguna untuk menggunakan teknologi yang baru maka semakin besar minat yang timbul dalam diri individu untuk menggunakan teknologi informasi tersebut karena adanya pengaruh lingkungan yang kuat.

\section{Facilitating Conditions}

Facilitating Conditions adalah tingat keyakinan individu akan infrastruktur dan fasilitas pendukung yang dimiliki oleh perusahaan atau organisasi tersedia untuk mendukung penggunaan sistem yang ada. Indikator dalam mengukur variable ini berdasarkan Thomas et. al. (2013) dan Marchewka et al. (2007) adalah pengetahuan yang dimiliki, kompatibilitas, ketersediaan bantuan dan sumberdaya.

\section{Behavioral Intention}

Behavioral Intention atau niat penggunaan teknologi informasi didefinisikan sebagai tingkat keinginan pengguna dalam memanfaatkan sistem 
yang ada secara terus menerus dengan anggapan mereka memiliki akses terhadap informasi. Model UTAUT membuktikan bahwa niat penggunaan dipengaruhi langsung oleh performance expectancy, effort expectancy dan social influence.

Thomas et. al.(2013) mengidentifikasi indikator yang digunakan untuk mengukur niat pemanfaatan yaitu keinginan untuk menggunakan terus menerus, keinginan untuk terus menggunakan dan rencana untuk terus menggunakan.

\section{Use Behavior}

Perilaku penggunaan didefinisikan sebagai intensitas atau frekuensi pemakai dalam menggunakan teknologi informasi. Perilaku penggunaan sangat bergantung pada kesan pengguna terhadap sistem yang ditawarkan. Sistem akan digunakan bila si pengguna berminat menggunakan dan memiliki keyakinan bahwa teknologi tersebut memberikan manfaat dalam membantu pekerjaannya, dapat digunakan dengan mudah serta adanya pengaruh sosial dari lingkungan sekitar.

Gandawati (2011) telah mengindentifikasi indikator dalam pengukuran perilaku penggunaan, yaitu kepuasan terhadap sistem, kepuasan penggunaan dan kepuasan berpengalaman.

\section{METODE}

Penelitian ini merupakan penelitian observasional analitik dengan rancang bangun menggunakan penelitian cross sectional. Penelitian dilakukan di RSUD dr. M. Soewandhi Surabaya. Waktu pelaksanaan penelitian ini dilakukan selama dua bulan. Populasi dalam penelitian ini adalah masyarakat yang berkunjung di RSUD dr. M. Soewandie kota Surabaya dengan rata-rata kunjungan per bulan sebesar 2774 orang. Sampel yang diteliti sebesar 100 orang yang akan dibagi dua kelompok yaitu kelompok pengguna 50 orang dan kelompok non pengguna 50 orang. Teknik pengambilan sampel yang digunakan adalah secara systematic random sampling.

Data primer diperoleh dengan menggunakan metode survey yaitu dengan memberikan kuesioner yang merupakan modifikasi dari penelitian Venkatesh et.al. (2003). Uji statistik dilakukan untuk melihat pengaruh variabel independen terdiri dari karakteristik individu, performance expectancy, effort expectancy, social influence dan facilitating conditions terhadap variabel dependen penelitian ini adalah use behavior dan behavioral intention.

\section{HASIL DAN PEMBAHASAN}

\section{Karakteristik Responden}

Karakteristik responden yang dinilai dalam penelitian ini antara lain usia, jenis kelamin, pendidikan, pekerjaan, pengalaman, pengetahuan tentang E-Health, dan kemampuan IT. Berdasarkan hasil penelitian pada tabel 2 menunjukkan bahwa usia responden pada kelompok non pengguna dan pengguna pendaftaran online mayoritas adalah kategori usia $\geq 51$ tahun.

Folland et. al. (2001) mengemukakan bahwa usia dapat mempengaruhi seseorang dalam melakukan pemanfaatan kesehatan dikarenakan perbedaan usia memiliki perbedaan resiko sakit. Sehingga mayoritas pengguna pelayanan 
kesehatan di RSUD dr. M. Soewandhie adalah lansia dengan kategori usia $\geq 51$ tahun.

Hasil uji pengaruh karakteristik responden pengguna terhadap use behavior terdapat tiga variabel yang memiliki $p<0,05$ yaitu pengalaman,

Tabel 2. Distribusi Responden berdasarkan Karakteristik Individu

\begin{tabular}{|c|c|c|c|c|c|c|c|}
\hline \multirow{2}{*}{ Karakteristik Individu } & \multicolumn{2}{|c|}{ Pengguna } & \multicolumn{2}{|c|}{ Non Pengguna } & \multicolumn{2}{|c|}{ Total } & \multirow[b]{2}{*}{$p$} \\
\hline & $\mathbf{n}$ & $\%$ & $\mathbf{N}$ & $\%$ & $\mathbf{N}$ & $\%$ & \\
\hline \multicolumn{8}{|l|}{ Usia } \\
\hline$<20$ tahun & 1 & 2 & 1 & 2 & 2 & 2 & \multirow{4}{*}{0,241} \\
\hline 21-35 tahun & 10 & 20 & 13 & 26 & 23 & 23 & \\
\hline $36-50$ tahun & 13 & 26 & 17 & 34 & 30 & 30 & \\
\hline$>51$ tahun & 26 & 52 & 19 & 38 & 45 & 45 & \\
\hline \multicolumn{8}{|l|}{ Jenis Kelamin } \\
\hline Perempuan & 31 & 62 & 32 & 64 & 63 & 63 & \multirow{2}{*}{0,836} \\
\hline Laki-laki & 19 & 38 & 18 & 36 & 37 & 37 & \\
\hline \multicolumn{8}{|l|}{ Pendidikan Terakhir } \\
\hline SD & 6 & 12 & 8 & 16 & 14 & 14 & \multirow{4}{*}{0,186} \\
\hline SMP & 10 & 20 & 12 & 24 & 22 & 22 & \\
\hline SMA & 20 & 40 & 22 & 44 & 42 & 42 & \\
\hline PT & 14 & 28 & 8 & 16 & 22 & 22 & \\
\hline \multicolumn{8}{|l|}{ Pekerjaan } \\
\hline PNS & 3 & 6 & 0 & 0 & 3 & 3 & \multirow{5}{*}{0,803} \\
\hline Pegawai Swasta & 13 & 26 & 16 & 32 & 29 & 29 & \\
\hline Ibu Rumah Tangga & 20 & 40 & 24 & 48 & 44 & 44 & \\
\hline Wiraswasta & 4 & 8 & 5 & 10 & 9 & 9 & \\
\hline Lain-lain & 10 & 20 & 5 & 10 & 15 & 15 & \\
\hline \multicolumn{8}{|l|}{ Pengetahuan } \\
\hline Tinggi & 29 & 58 & 6 & 12 & 35 & 41 & \multirow{3}{*}{0,000} \\
\hline Cukup & 18 & 36 & 30 & 60 & 48 & 48 & \\
\hline Kurang & 3 & 6 & 14 & 28 & 17 & 17 & \\
\hline \multicolumn{8}{|l|}{ Kemampuan IT } \\
\hline Baik & 39 & 78 & 25 & 50 & 64 & 64 & \multirow[t]{2}{*}{0,004} \\
\hline Kurang baik & 11 & 22 & 25 & 50 & 36 & 36 & \\
\hline \multicolumn{8}{|l|}{ Pengalaman } \\
\hline Tidak pernah & 0 & 0 & 50 & 100 & 50 & 100 & \multirow{4}{*}{0,000} \\
\hline 1-3 kali & 28 & 56 & 0 & 0 & 28 & 56 & \\
\hline 4-6 kali & 7 & 14 & 0 & 0 & 7 & 14 & \\
\hline$>6$ kali & 15 & 30 & 0 & 0 & 15 & 30 & \\
\hline
\end{tabular}

Mayoritas responden berjenis kelamin

perempuan. Tingkat pendidikan responden sebagian besar SMA, PT dan SMP dengan mayoritas pekerjaan sebagai ibu rumah tangga.

Pada kelompok pengguna pendaftaran online sebagian besar memiliki pengetahuan yang tinggi mengenai $E$-Health dengan tingkat mayoritas kemampuan IT yang baik. Sedangkan kelompok non pengguna mayoritas memiliki tingkat pengetahuan $E$-Health yang cukup dan kemampuan IT dengan persentase $50 \%$ baik dan $50 \%$ kurang baik. kemampuan IT dan pengetahuan terhadap $E$ Health. Sehingga dapat disimpulkan bahwa variabel pengalaman, kemampuan IT dan pengetahuan berpengaruh secara signifikan terhadap use behavior pendaftaran online.

Kemampuan merupakan kapasitas individu untuk mengerjakan berbagai tugas yang ia terima (Syahrifah, 2010). Kemampuan IT yang dituntut dalam mengoprasikan mesin E-Kios adalah browsing internet dan penggunaan perangkat elektronik yang berbasis layar sentuh. Sehingga pengguna dengan kemampuan IT yang tinggi dapat 
mempengaruhi penggunaan sistem pendaftaran online.

Menurut Frambach dan Schillewaert (1999), salah satu karakteristik individual yang penting dalam individual acceptance adalah pengalaman penggunaan produk sejenis sebelumnya. Hal ini berarti bahwa pengguna dengan pengalaman yang tinggi memiliki individual acceptance yang besar.

Selain faktor pengalaman, pengetahuan merupakan salah satu faktor predisposisi untuk terjadinya perilaku (Green,1980). Semakin baik pengetahuan tentang E-Health yang dimiliki pengguna maka semakin mudah untuk melakukan proses pendaftaran online.

\section{Performance expectancy}

Performance expectancy merupakan tingkat kepercayaan seseorang dalam penggunaan teknologi dapat meningkatkan kinerja orang tersebut. Terdapat empat indikator yang digunakan yaitu persepsi adanya kemanfaatan, dapat meningkatkan kepuasan, menghemat waktu dan memberikan keuntungan.

Tabel 3. Distribusi Penilaian Performance Expectancy

\begin{tabular}{|c|c|c|c|c|c|}
\hline \multirow[t]{2}{*}{ Kategori } & \multicolumn{2}{|c|}{ Pengguna } & \multicolumn{2}{|c|}{$\begin{array}{c}\text { Non } \\
\text { Pengguna }\end{array}$} & \multirow[t]{2}{*}{$p$} \\
\hline & $\mathbf{N}$ & $\%$ & $\mathbf{n}$ & $\%$ & \\
\hline Kurang Baik & 4 & 8 & 2 & 4 & \multirow{3}{*}{0,044} \\
\hline Baik & 46 & 92 & 48 & 96 & \\
\hline Total & 50 & 100 & 50 & 100 & \\
\hline
\end{tabular}

Berdasarkan tabel 3 dapat disimpulkan bahwa mayoritas kelompok pengguna memberikan penilaian yang baik dengan persentase $92 \%$ sedangkan kelompok non pengguna sebesar $96 \%$. Hasil penilaian pengguna dan non pengguna terhadap performance expectancy adalah kategori baik. Sehingga dapat disimpulkan bahwa responden yang terdiri dari kelompok pengguna dan non pengguna merasa bahwa manfaat dari E-Health dapat membantu mempermudah dalam melakukan proses pendaftaran.

Berdasarkan hasil uji statistik variabel performance expectancy memiliki nilai $(p<0,05)$ sehingga memberikan pengaruh yang signifikan terhadap behavioral intention. Hasil penelitian ini sejalan dengan Pardamean dan Susanto (2012) yang menyatakan bahwa performance expectancy memiliki efek yang sangat kuat dalam behavioral intention dari segala aspek.

\section{Effort Expectancy}

Effort Expectancy adalah persepsi tingkat kemudahan yang terkait dalam penggunaan teknologi, adapun indikator yang digunakan dalam penilaian adalah kemudahan perencanaan kunjungan, pengoprasian mesin, kemudahan untuk dipelajari dan kecepatan pelayanan dibandingkan manual.

Tabel 4. Distribusi Penilaian Effort Expectancy

\begin{tabular}{|c|c|c|c|c|c|}
\hline \multirow{2}{*}{ Kategori } & \multicolumn{2}{|c|}{ Pengguna } & \multicolumn{2}{|c|}{$\begin{array}{c}\text { Non } \\
\text { Pengguna }\end{array}$} & \multirow[t]{2}{*}{$p$} \\
\hline & $\mathbf{N}$ & $\%$ & $n$ & $\%$ & \\
\hline Kurang Baik & 2 & 4 & 4 & 8 & \\
\hline Baik & 48 & 96 & 46 & 92 & 0,982 \\
\hline Total & 50 & 100 & 50 & 100 & \\
\hline
\end{tabular}

Hasil pada tabel 4 menunjukkan bahwa mayoritas kelompok pengguna sebesar $96 \%$ dan kelompok non pengguna 92\% memberikan penilaian baik. Sehingga responden merasa bahwa penggunaan pendaftaran online dapat memberikan kemudahan dalam memperoleh layanan di rumah sakit. 
Tingkat kemudahan penggunaan suatu sistem akan mempengaruhi niat untuk menggunakan sistem tersebut (Venkatesh et al, 2003). Penelitian ini menemukan hasil yang berbeda yaitu effort expectancy memiliki nilai $p>0,05$ sehingga tidak memberikan pengaruh yang signifikan terhadap behavioral intention. Hasil ini sejalan dengan Dasgupta et al (2007), yang meneliti penerimaan pengguna dalam menganalisis dan mendesain suatu sistem juga menemukan pengaruh yang tidak signifikan antara effort expectancy dengan behavioral intention.

\section{Social Influence}

Penilaian social influence untuk mengetahui tingkat dimana individu merasa dipengaruhi oleh lingkungan sosial dalam menggunakan teknologi dapat dinilai dengan tiga indikator yaitu pemakaian karena melihat orang lain, pemakaian karena disuruh oleh orang lain dan kepercayaan akan adanya bantuan orang lain bila mengalami kesulitan pengoprasian teknologi.

Tabel 5. Distribusi Penilaian Social Influence

\begin{tabular}{lccccc}
\hline \multirow{2}{*}{ Kategori } & \multicolumn{2}{c}{ Pengguna } & \multicolumn{2}{c}{$\begin{array}{c}\text { Non } \\
\text { Pengguna }\end{array}$} & $\boldsymbol{p}$ \\
\cline { 2 - 3 } & $\mathbf{n}$ & $\%$ & $\mathbf{n}$ & $\%$ & \\
\hline $\begin{array}{l}\text { Tidak } \\
\text { terpengaruh }\end{array}$ & 13 & 26 & 13 & 26 \\
$\begin{array}{l}\text { lingkungan } \\
\text { sosial }\end{array}$ & & & & & \\
\hline $\begin{array}{l}\text { Terpengaruh } \\
\text { lingkungan } \\
\text { sosial }\end{array}$ & 37 & 74 & 37 & 74 & \\
\hline Total & 50 & 100 & 50 & 100 \\
\hline
\end{tabular}

Pada tabel diatas dapat diketahui bahwa mayoritas kelompok pengguna maupun kelompok non pengguna telah terpengaruh lingkungan sosial dengan persentase 74\%. Handayani (2007) menuturkan bahwa social influence merupakan pengaruh dari lingkungan sekitar yang meyakinkan individu untuk menggunakan informasi teknologi. Hasil penelitian ini sejalan dengan pernyataan tersebut karena kelompok pengguna dan non pengguna menilai bahwa mereka terpengaruh lingkungan sosial dalam pengambilan keputusan penggunaan E-Health.

Namun secara hitungan statistik dengan uji pengaruh diperoleh hasil nilai $p>0,05$ sehingga variabel social influence tidak berpengaruh secara signifikan terhadap behavioral intention. Hasil ini tidak sejalan dengan Hartati (2013) yang meninjau pengaruh social influence memiliki nilai yang signifikan terhadap penerapan e-government di Kota Palembang.

\section{Facilitating Condition}

Kondisi yang memfasilitasi pengguna sistem teknologi informasi merupakan salah satu faktor yang mempengaruhi pemanfaatan sistem teknologi informasi (Sigalotang et al, 2006). Indikator yang digunakan dalam penilaian facilitating conditions antara lain tampilan fisik mesin E-Kios, koneksi internet yang lancar, tampilan menu yang jelas dan proses pencetakan nomor antrian yang lancar.

Tabel 6. Distribusi Penilaian Facilitating Conditions

\begin{tabular}{|c|c|c|c|c|c|}
\hline \multirow{2}{*}{ Kategori } & \multicolumn{2}{|c|}{ Pengguna } & \multicolumn{2}{|c|}{$\begin{array}{c}\text { Non } \\
\text { Pengguna }\end{array}$} & \multirow{2}{*}{$p$} \\
\hline & 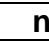 & $\%$ & $\mathbf{n}$ & $\%$ & \\
\hline Kurang Baik & 11 & 22 & 12 & 24 & \multirow{3}{*}{0,812} \\
\hline Baik & 39 & 78 & 38 & 76 & \\
\hline Total & 50 & 100 & 50 & 100 & \\
\hline
\end{tabular}

Berdasarkan tabel 6 dapat disimpulkan bahwa mayoritas kelompok pengguna memberikan penilaian yang baik dengan persentase $78 \%$ sedangkan kelompok non pengguna sebesar $76 \%$. Namun berdasarkan hasil uji statistik pengaruh variabel facilitating condition terhadap use behavior 
memiliki nilai $p>0,05$ sehingga dapat disimpulkan bahwa variabel facilitating condition tidak berpengaruh terhadap use behavior.

Hasil penelitian ini tidak sesuai dengan penelitian yang dilakukan Hamzah (2009) tentang pemanfaatan sistem informasi di Madura dimana variabel kondisi yang memfasilitasi pemakai memiliki pengaruh terhadap minat pemanfaatan sistem informasi. Menurut Sedana dan Wijaya (2009) kemungkinan tidak signifikannya pengaruh facilitating conditions terhadap use behavior karena pada saat uji statistik tidak memasukkan variabel moderator usia dan pengalaman. Pada teori UTAUT (Venkatesh, 2003) konstruk facilitating conditions apabila dimoderasi oleh usia dan pengalaman maka akan memiliki pengaruh yang signifikan terhadap use behavior.

\section{Behavioral Intention}

Behavioral Intention merupakan kekuatan niat seseorang untuk melakukan perilaku tertentu, meliputi keinginan untuk menggunakan di kesempatan selanjutnya, keinginan untuk memberikan komentar positif, keinginan untuk merekomendasikan teknologi pada orang lain.

Tabel 7. Distribusi Penilaian Behavioral Intention

\begin{tabular}{|c|c|c|c|c|c|}
\hline \multirow[t]{2}{*}{ Kategori } & \multicolumn{2}{|c|}{ Pengguna } & \multicolumn{2}{|c|}{$\begin{array}{c}\text { Non } \\
\text { Pengguna }\end{array}$} & \multirow[t]{2}{*}{$\mathbf{p}$} \\
\hline & $\mathbf{n}$ & $\%$ & $\mathbf{n}$ & $\%$ & \\
\hline Niat Rendah & 10 & 20 & 5 & 10 & \multirow{3}{*}{0,189} \\
\hline Niat Tinggi & 40 & 80 & 45 & 90 & \\
\hline Total & 50 & 100 & 50 & 100 & \\
\hline
\end{tabular}

Hasil pada tabel 7 menunjukkan bahwa mayoritas kelompok non pengguna sebesar $90 \%$ mempunyai niat tinggi. Selanjutnya $10 \%$ kelompok non pengguna yang memiliki niat rendah. Pada kelompok pengguna katgori niat tinggi mempunyai persentase sebesar $80 \%$ dan kategori niat rendah sebesar $20 \%$. Hasil uji statistik menunjukkan bahwa nilai $p>0,05$ sehingga dapat disimpulkan bahwa behavioral intention tidak mempengaruhi use behavior.

Hasil penelitian tidak sejalan dengan teori UTAUT serta penelitian oleh Nammah dan Sensuse (2013) yang menyatakan bahwa behavioral intention berpengaruh terhadap use behavior. Hal ini dapat disebabkan penerapan pendaftaran online belum dilaksanakan secara optimal karena sebagian pendaftar memilih untuk menggunakan cara manual.

\section{SIMPULAN}

Hasil penelitian menunjukkan bahwa karakteristik responden yang berpengaruh terhadap penggunaan E-Health adalah pengalaman, pengetahuan dan kemampuan IT. Sedangkan faktor yang berpengaruh terhadap niat perilaku penggunaan pendaftaran online adalah performance expectancy. Sehingga responden menganggap bahwa dengan menggunakan pendaftaran online mampu meningkatkan kepuasan, keuntungan dan penghematan waktu tunggu.

Pemerintah Kota Surabaya dapat menggunakan hasil penelitian ini untuk mengoptimalkan penerapan sistem pendaftaran online atau E-Health. Saran yang dapat diberikan adalah pihak pemerintah perlu memberikan sosialisasi mengenai keuntungan mendaftar secara online kepada masyarakat melalui media yang menarik sehingga diharapkan mampu 
meningkatkan pengetahuan serta menumbuhkan

minat masyarakat untuk mendaftar secara online.

Selain itu pihak rumah sakit dapat menyediakan

petugas pendamping yang selalu stand by untuk melatih kemampuan IT dan membantu para pendaftar online yang kesulitan dalam mengakses E-Health.

\section{DAFTAR PUSTAKA}

Dasgupta, S., M. Haddad, P. Weiss, E. Bermudez. (2007). User Acceptance of Case Tools in System Analysis and Design: an Empirical Study, Journal of Informatics Education Research, Vol 9. Pp 51-78.

Folland, et. al. (2001). The Economic of Health and Health Care.Third Edition. New Jersey: Prentis Hall Inc.

Frambach, Rudd T. and Niels Schillewaert. (1999). Organizational Innovation Adoption: A MultiLevel Framework of Determinants and Opportunities for Future Research. USA: The Pennsylvania State University.

Gandawati, T.S. (2011). Analisi Proses Adopsi Electronic Payment Sistem dengan menggunakan UTAUT Model (Studi Pada Sistem Pembayaran Online Kaspay di Kaskus). Tesis. Depok: Universitas Gunadarma.

Green, L.W. (1980). Health Education Planning: a Diagnostic Approach. First edition. California: Mayfield Publishing Company

Hamzah, A. (2009). Pengaruh Ekspektasi Kinerja, Ekspektasi Usaha, Faktor Sosial sesuaian Tugas dan Kondisi yang Memfasilitasi Pemakai Terhadap Minat Pemanfaatan Sistem Informasi (Studi Empiris pada Pemerintahan Kab di Madura). Simposium Nasional Teknologi Informasi. Yogyakarta: Universitas Gajah Mada.

Handayani, R. (2007). Analisis Faktor-Faktor yang Mempengaruhi Minat Pemanfaatan Sistem Informasi dan Penggunaan Sistem Informasi (Studi Empiris pada Perusahaan Manufaktur di Bursa Efek Jakarta). Jurnal Akutansi dan Keuangan, Vol. 9 No.2 pp 76-87.

Hartati, Ery. (2013). Faktor-faktor Yang Berpengaruh Terhadap Efektivitas Penerapan E-Government dengan Menggunakan Metode UTAUT (Unified Theory of Acceptance and Use of Technology) di Kota Palembang. Seminar Nasional Teknologi Informasi dan Multimedia. Yogyakarta: STMIK AMIKOM.

Jati, N.J. dan Laksito, H. (2012). Analisis FaktorFaktor yang Mempengaruhi Minat Pemanfaatan dan Penggunaan Sistem ETicketing (Studi Empiris pada Biro Perjalanan di Kota Semarang). Skripsi. Semarang: Universitas Diponegoro.

Joaquin, Blaya.A., Fraser, H.S.F., Holt, B. (2010). EHealth technologies show promise in developing countries. Health Affairs, 29 (2), 244-51.

Marchewka, J.T., Liu, C., dan Kostiwa, K. (2007). An Application of the UTAUT Model for Understanding Student Perceptions Using Course Management Software. Communication of the IIMA, Vol 7, Nomor 2 pp 93-104.

Nammah, C.D., Dana I. S. (2013). Analisis Penerimaan Teknologi Internet oleh Pengajar dengan Menggunakan Model Unified Theory of Acceptance and Use of Technology. Jurnal Fakultas IImu Komputer UI Depok.

Parmadamean dan Susanto, (2012). Assesing User Acceptance toward Blog Technology Using the UTAUT Model. International Journal of Mathematics and Computers in Simulation, pp. Issue 1, Vol. 6.

Sa'idah, Nurus. (2016). Analisis Use Behavior Pada Sistem Pendaftaran Online E-Health menggunakan Unified Theory of Acceptance and Use of Technology (UTAUT). Skripsi. Surabaya: Universitas Airlangga.

Sari, Indah Novita. (2013). Analisa Model UTAUT pada Brawijaka Knowledge Garden (Studi Eksplanatif Penerimaan dan Penggunaan Sistem Brawijaya Knowledge Garden pada Universitas Brawijaya). Skripsi. Surabaya: Universitas Airlangga.

Sedana, IGN., dan Wijaya, S.W. (2009). Penerapan Model UTAUT untuk Memahami Penerimaan dan Penggunaan Learning Management System Studi Kasus: Experential E-Learning of Sanata Dharma University. Journal of Informations System,5 (2), pp 114-120.

Sigalotang, W.A., Pontoh,G.T., dan Syahrir. (2006). Analisis Determinan Pemanfaatan Sistem Informasi dan Teknologi Informasi dan Pengaruhnya terhadap Kinerja Karyawan Bank di Kota Makassar. Jurnal Ekonomi Bisnis dan Akutansi Ventura, Vol. 19, No. 13.

Syahrifah, Nur Lailatus. (2010). Analisis Pengaruh Sikap, Kemampuan, Keterampilan dan Waktu Tunggu terhadap Mutu Layanan Laboratorium di RS Semen Gresik. Skripsi. Surabaya: Universitas Airlangga

Thomas, T.D., Singh, L. dan Gaffar, K. (2013). The utility of the UTAUT model in explaining mobile learning adoption in higher education in Guyama. International Journal of Education and Development using Information and Communication Technology, 9(3), 71.

Venkatesh, V. dan Davis, F.D. (2000). A Theoritical Extension of The Technology Acceptance Model: Four Longitudinal Field Studies. Management Science. 46 (2). 186-204.

Venkatesh, V., M.G. Morris, G.B. Davis and F.D. Davis (2003). User Acceptance of Information Technology:Toward a Unified View. USA: MISRC University of Minnesota.

Wickramasinghe dan Goldberg. (2004). How $\mathrm{M}=\mathrm{ec}^{2}$ In Healthcare. International Journal of 
Management and Enterprise Development, Vol 4 (1), hal 52-65.
WHO. (2008). Health Information System. Jeneva: WHO. 